PAEDAGOGIA ChRISTIANA

1/21 (2008) - ISSN 1505-6872

Edwin Miller*

Chełmno

\title{
Osiągnięcia bł. Bolesławy Lament i założonego przez nią Zgromadzenia Sióstr Misjonarek Świętej Rodziny na gruncie pracy wychowawczo-duszpasterskiej w latach 1905-1991
}

\section{Zapowiedź tematu}

Poniższy artykuł w połączeniu $\mathrm{z}$ innymi opracowaniami na ten temat ${ }^{1}$ ma na celu upowszechnienie wiedzy o osiagnięciach Sióstr Misjonarek na gruncie pracy wychowawczo-duszpasterskiej. Nie chodzi tu tylko o chęć uchronienia dorobku Sióstr od zapomnienia, ale chodzi przede wszystkim o wzór zaangażowania pedagogicznego, katechetycznego, z którego możemy obecnie czerpać, gdy od osiemnastu lat budujemy społeczeństwo obywatelskie. Nie chcieć skorzystać

${ }^{*}$ Ks. dr Edwin Miller, kapelan w domu formacyjnym Sióstr Misjonarek Świętej Rodziny w Chełmnie na Pomorzu; prowadzi wykłady z teologii dla postulantek i nowicjuszek. Autor Zamyśleń, popularnonaukowych rozważań biblijnych.

${ }^{1}$ Ważniejsze publikacje: prace doktorskie: D. Karwowska, Historia Zgromadzenia Sióstr Misjonarek Świętej Rodziny w latach 1945-1967, Warszawa 1998 (mps); E. Miller, Działalność wychowawczo-duszpasterska Zgromadzenia Sióstr Misjonarek Świętej Rodziny od 1905 do 1991 roku, Warszawa 2001 (mps); prace magisterskie: L. Puciłowska, Działalność społeczno-pedagogiczna Zgromadzenia SS. Misjonarek Świętej Rodziny (1905-1939), Lublin 1970 (mps.); B. Rajkowska, Działalność misyjna Zgromadzenia Sióstr Misjonarek Św. Rodziny w Zambii (1970-1980), Warszawa 1981 (mps.); R. Filipowicz, Udział Sióstr Misjonarek Świętej Rodziny w procesie dojrzewania Kościoła zambijskiego w latach 1980-1992, Warszawa 1994 (mps); A. Rzymska, Ekumenizm Bolesławy Lament, Rzym 1986 (mps); opracowania książkowe: J. Bar, Wybór pism Bolesławy Lament, Rzym 1975; A. Gronkiewicz, Życie i działalność Bolesławy Marii Lament 1862-1946 Założycielki Zgromadzenia Sióstr Misjonarek św. Rodziny, Warszawa 1990; J. Stabińska, Szukać i zbawiać. Posłannictwo Bolesławy Lament, Warszawa 1991. 
z dorobku Sióstr oraz innych zgromadzeń zakonnych czy środowisk wychowawczych byłoby wielkim marnotrawstwem. Dzisiaj, gdy tak dynamicznie rozwija się polska pedagogika i katechetyka, konieczne jest, aby dokonać całościowego spojrzenia na te dziedziny nauki, a nie ulega wątpliwości, że i Siostry Misjonarki mają w tym swój udział.

Pedagogiczne zaangażowanie Sióstr ciagle trwa, ale my w ramach tego tekstu ograniczymy się do lat 1905-1991. Te graniczne daty są wyznaczone przez rok 1905 - jest to moment powołania do istnienia Zgromadzenia Sióstr Misjonarek Świętej Rodziny przez bł. Bolesławę Lament oraz rok 1991 - wtedy to odbyła się uroczysta beatyfikacja Matki Założycielki. Są to dwie proste daty, ale w tej cezurze czasowej zawiera się całe bogactwo wydarzeń historycznych, które omówimy w punkcie Tlo historyczne.

Przez te wszystkie lata Zgromadzenie pozostało wierne charyzmatowi, który wyznaczyła mu Założycielka, mianowicie jest to: praca ekumeniczna, głównie w odniesieniu do Kościoła prawosławnego oraz praca nad pogłębieniem i umocnieniem ducha religijnego i patriotycznego pośród rodaków żyjących w rozproszeniu. W celu osiagnięcia wyznaczonego zadania Siostry koncentrowały się najwięcej nad kształceniem dzieci i młodzieży w naukach świeckich i w religii. Kształcenie to realizowane było na wiele sposobów: przez katechizację, animację liturgiczną, przez tworzenie ośrodków opiekuńczo-wychowawczych i zakładów oświatowych. Chcąc szerzej opisać metody, z których Siostry korzystały w swej pracy, należy zauważyć, że początkowo były to czasy zaboru rosyjskiego, a więc i metody były proste, dodatkowo były one poddane rygoryzmowi konspiracji. Temu zagadnieniu oraz osobie Założycielki Zgromadzenia poświęcimy dwa kolejne punkty. Przy czym mówiąc o metodach, a raczej o systemie wychowawczym, poszerzymy trzeci punkt o pozostałe lata, poza czasy zaboru oraz o opis zabiegów wychowawczych, które były adresowane do ludzi świeckich, czyli na zewnątrz Zgromadzenia, ale też były skierowane do samych Sióstr, czyli do wnętrza Zgromadzenia.

Całość tego opracowania zostanie zamknięta przez wymienienie konkretnych prac i ośrodków, w których Siostry pełniły tak owocne posłannictwo wychowawczo-duszpasterskie. I tak: katechizacja i animacja liturgiczna odbywała się w parafiach, w stowarzyszeniach i ruchach świeckich katolików. Do tworzonych ośrodków opiekuńczo-wychowawczych należały żłobki, sierocińce, przedszkola, zakłady opieki społecznej, internaty. Z kolei do zakładów oświatowych zaliczano szkoły powszechne i średnie oraz wszelkiego rodzaju kursy zawodowe.

\section{Tho historyczne}

Rok 1905, kiedy zaistniało Zgromadzenie Sióstr Misjonarek Św. Rodziny, wpisuje się w tragiczny ciąg dat, kiedy Polska została wymazana z mapy Europy. W wyniku kolejno przeprowadzonych rozbiorów ziemie, na których urodziła 
się bł. Bolesława Lament, a potem powstało Zgromadzenie, zostały siłą wcielone do Cesarstwa Rosyjskiego, które zamierzało podporządkować sobie naród polski. Polacy, próbując zrzucić pęta niewoli, wywołali kilka powstań narodowych. W wyniku ich upadku utracili jednak wszelkie pozory autonomii. Najdotkliwszy cios zaborca zadał kulturze narodowej. Odtąd język rosyjski stał się językiem obowiązkowym na całym obszarze zaboru. Używanie języka polskiego zostało zabronione pod sankcją kary. Najsroższych kar doświadczyli uczestnicy powstań, a zwłaszcza inteligencja polska. Ci, którzy nie zdążyli emigrować do krajów zachodnich, najczęściej byli skazywani na katorgę. Represji nie uniknął również Kościół katolicki. Caryca Katarzyna ingerowała w strukturę administracyjną Kościoła. Dokonywała samowolnych zmian granic diecezji i lokalizacji stolic biskupich. Podobnie czynił car Aleksander II. To z jego strony po upadku powstania styczniowego dotkliwych represji doświadczyły zakony, uważał je bowiem za źródło niezależnej myśli i ducha patriotycznego Polaków. Car nakazał rozwiązać większość zakonów. Nie pozwalał przyjmować nowych powołań. Dlatego liczni duchowni zostali zmuszeni przejść do tzw. podziemia, czyli działali w konspiracji ${ }^{2}$. Takiej szansy na przetrwanie nie miał Kościół unicki w Polsce. Carowie nie okazali jemu żadnej tolerancji z tego powodu, że unitów uważali za prawosławnych, dlatego w 1839 r. skasowano ich Kościół na polskich ziemiach wschodnich, a w 1875 r. tego samego dokonano w Królestwie Kongresowym. Unitów wcielono siłą do cerkwi ${ }^{3}$. Najtragiczniejszy jednakże czas jest związany z wybuchem rewolucji z 1917 r. i rządami bolszewików, ponieważ wtedy nastąpił okres totalnego niszczenia samej religii. Oczywiście odnosi się to do tych Polaków i tych terenów, które znalazły się poza granicami odrodzonej w 1918 roku Rzeczypospolitej Polskiej ${ }^{4}$.

Odrodzona po długotrwałej niewoli II Rzeczypospolita była państwem wielonarodowościowym i wielowyznaniowym. Polacy stanowili 65\% ludności, Ukraińcy $16 \%$, Żydzi 10\%, Białorusini 5\%, Niemcy 4\%, pozostali 1\%. Jeżeli chodzi o wyznanie, Kościół rzymskokatolicki obejmował 62\% mieszkańców Polski, grekokatolicki, reprezentowany głównie przez Ukraińców, 12\%. Kościół prawosławny skupiał $11 \%$ wiernych, głównie Rosjan i Białorusinów. Religię mojżeszową wyznawało około $11 \%$ obywateli, a około $5 \%$ ludzi reprezentowało kościoły protestanckie ${ }^{5}$. Wraz z uzyskaniem suwerenności narodowej diametralnej zmianie uległa pozycja ludzi wierzących. Kościół katolicki, jak i inne wyznania, otrzymał pełną wolność działania. Kościół katolicki wykorzystał istniejącą szansę rozwoju. Podstawową misją Kościoła była praca na rzecz integracji Polaków z trzech zaborów. W okresie dwudziestolecia międzywojennego istotną rolę

${ }^{2}$ Zob. A. Gronkiewicz, dz. cyt., s. 23-26; 59-65.

${ }^{3}$ Zob. J. Giertych, Tysiac lat historii polskiego narodu, Londyn 1986, t. 1, s. 293-299.

${ }^{4}$ Zob. B. Kumor, Historia Kościoła - czasy wspótczesne 1914-1992, Lublin 1995, s. $208-212$.

${ }^{5}$ Zob. W. Roszkowski, Historia Polski 1914-1994, Warszawa 1995, s. 32. 
w odnowie i scalaniu ziem polskich spełniały dynamicznie rozwijające się zakony męskie i żeńskie. Każdy zakon w swej misji kierował się charakterystycznym dla siebie charyzmatem posługi duszpasterskiej. Stąd zakony angażowały się we wszystkie przejawy życia społecznego i religijnego. W Polsce w 1937 r. było 311 klasztorów i domów zakonnych męskich z 5767 duchownymi. Liczba klasztorów i domów zakonnych w porównaniu do 1918 r. zwiększyła się o 141 placówek. W okresie międzywojennym przybyło do Polski dziewięć nowych zgromadzeń zakonnych męskich, które liczyły 30 klasztorów i 708 zakonników. W tym samym 1937 r. było w kraju 1686 klasztorów i domów zakonnych żeńskich, w których przebywało 16820 sióstr zakonnych ${ }^{6}$. Także duchowieństwo diecezjalne, jak i katolicy świeccy prężnie działali. W tym miejscu można jedynie skrótowo wymienić inicjatywy, jakie podejmował Kościół polski: na nowo zaczęły odradzać się seminaria duchowne, wydziały teologiczne na uniwersytetach, a katecheza powróciła do szkoły. Wznowiły swą działalność wydawnictwa katolickie, stowarzyszenia życia religijnego, apostolskiego, jak III Zakon św. Franciszka, Sodalicja Mariańska oraz różne bractwa, jak: Apostolstwo Modlitwy, Róże Różańcowe, Bractwo Szkaplerza Świętego, Bractwo Straży Honorowej, Krucjata Eucharystyczna oraz liczne organizacje społeczno-religijne. Chodzi tu o związki pracownicze, a także Związek Polskiej Inteligencji, na czele z Akcją Katolicką. Ze względu na znaczne zubożenie społeczeństwa szeroko rozwinęły swą działalność organizacje charytatywne i dobroczynne ${ }^{7}$.

Tak pięknie zapowiadającą się pracę Kościoła i społeczeństwa polskiego przerwał w 1939 r. atak dwóch najeźdźców: na Zachodzie Niemców hitlerowskich, a na Wschodzie Rosji Sowieckiej ${ }^{8}$. Okupant niemiecki od razu przystapił do eksterminacji kleru. Spośród 12154 duchownych polskiego pochodzenia 1780 więziono w największym obozie koncentracyjnym dla księży w Dachau. Z tego grona zginęło 799 duchownych ${ }^{9}$. Nie mniej przerażająca jest skala prześladowanej ludności cywilnej. Wiele tysięcy osób zginęło w walkach, podczas publicznych egzekucji czy zostało wywiezionych do obozów koncentracyjnych. Olbrzymią liczbę ludzi skierowano na przymusowe roboty do Niemiec ${ }^{10}$. Nie sposób w tym miejscu pominać milczeniem losu Żydów, którzy także byli obywatelami Polski. Według szacunkowych obliczeń, przyjmuje się, że naziści podczas wojny zamordowali 2,7 mln Żydów z terenów całej II Rzeczypospolitej. Wobec tej tragedii Kościół polski próbował przyjść tym ofiarom z pomocą. Pomoc tę kierowano głównie do dzieci, którym wystawiano fałszywe metryki chrztu i ukrywano je w obiektach sakralnych lub w rodzinach polskich ${ }^{11}$. Okupacja sowiecka

${ }^{6}$ Zob. B. Kumor, dz. cyt., s. 401, 403.

${ }^{7}$ Zob. E. Miller, dz. cyt., s. 47-48.

${ }^{8}$ Zob. B. Kumor, dz. cyt., s. 430-431, 433.

${ }^{9}$ Zob. F. Stopniak, Kościót na ziemiach polskich w latach 1848-1978, w: L. J. Rogier, R. Aubert, M. D. Knowles (red.), Historia Kościoła, Warszawa 1985, t. 5, s. 595.

${ }^{10}$ Zob. B. Kumor, dz. cyt., s. 495-461.

${ }^{11}$ Zob. tamże, s. 464-466. 
wschodniej Polski trwała od 1939 r. do 1941 r., do wybuchu wojny niemiecko-radzieckiej. Metody terroru bolszewików wobec Polaków były równie okrutne jak niemieckie. Służba bezpieczeństwa rozpoczęła swoje represje od aresztowania i likwidacji średnich i wyższych klas społecznych. W ślad za tym szły najczęściej aresztowania ich rodzin, a następnie zsyłki w głąb państwa ${ }^{12}$.

Gdy w 1945 r. skończyła się wojna i nastał upragniony pokój, Polacy szybko przekonali się, że są to pozory wolności i niezawisłości ojczyzny. Polska dostała się w sferę wpływów radzieckich. W wyniku sfałszowanych wyborów z $1947 \mathrm{r}$. komuniści przejęli władzę w kraju. Władze wspierane przez radziecką i polską służbę bezpieczeństwa przystapiły do likwidacji wszelkiej opozycji. Za wroga Polski Ludowej uznano i Kościól. Niezależnie jednak od postawy komunistów, Kościół świadomy swych obowiązków względem ojczyzny, podjął się misji jednoczenia narodu, zwłaszcza gdy chodzi o tzw. ziemie odzyskane. Wraz z przesiedlaną ludnością na te ziemie przybyły i polskie zakony. Zgromadzenia te wcześniej ograbione na Wschodzie, uciekały do Polski przed dalszymi represjami. Prymas Polski kard. August Hlond na tych terenach szybko ustanowił polską administrację kościelną. Również szybko przystapiono do odbudowy struktury materialnej w skali całego Kościoła. Na nowo zaczęto otwierać seminaria duchowne i wydziały teologiczne, a katecheza znów zagościła w szkole. Drukarnie wznowiły druk prasy i literatury religijnej. Reaktywowały swą działalność stowarzyszenia i bractwa religijne, a także organizacje charytatywne. Pomimo tych pozytywów, komuniści w sposób jawny podjęli konfrontację z Kościołem i ludźmi wierzącymi. Nieprzyjazne działania i decyzje były stopniowane i odnosiły się właściwie do wszystkich dziedzin życia Kościoła. Władze wtrącały się w obsadę stanowisk w Kościele. Prowadziły inwigilację, podsłuchy, medialną nagonkę na osoby duchowne i ich współpracowników, bezprawnie przejmowały majątek kościelny. Były i bardziej groźne działania, jak więzienie, fikcyjne procesy, pobicia, a nawet zabójstwa niewygodnych osób. Wobec tych i innych zagrożeń Prymas Polski abp Stefan Wyszyński w 1950 r. podpisał umowę z władzami, która miała regulować stosunki państwo-Kościół. Jednak komuniści nie zamierzali respektować tej umowy, dlatego w 1953 r. przeciw stosowanemu bezprawiu wystapił Episkopat Polski. W reakcji na to służba bezpieczeństwa uwięziła Prymasa. Ten stan trwał do 1956 r., kiedy wobec wybuchu niepokojów społecznych w Poznaniu, w dużej mierze na tle ekonomicznym, partia komunistyczna ugięła się i przyznała Kościołowi pewną swobodę działania, zwolniono także kard. St. Wyszyńskiego. Po wyciszeniu kryzysu społecznego w 1958 r. wznowiono wrogą działalność wobec Kościoła. Komuniści zaczęli rugować katechezę ze szkół, alumnów powoływali do wojska, siostry zakonne zwalniali ze szpitali, szkół i przedszkoli. Kolejne kryzysy społeczne, przyczyniły się jednak do upadku komunizmu w naszym kraju. Ten ruch wolnościowy był możliwy, ponieważ polskie społeczeństwo posiadało stałe wsparcie w strukturach Kościoła, chodzi tu głównie o siłę duchową i inte-

${ }^{12}$ Zob. tamże, s. 452-453; W. Roszkowski, dz. cyt., s. 97-98. 
lektualną wiary chrześcijańskiej. Siłę tę Polacy zyskiwali zwłaszcza z posługi apostolskiej rodaka, papieża Jana Pawła II (1978-2005). Proces nabywania przez społeczeństwo podmiotowych praw obywatelskich był już nie do zatrzymania. Ostatecznie na przełomie 1989 i 1990 r. upadł w Polsce komunizm. Od tego momentu Kościół, zgodnie ze swoją misją, włącza się w proces budowania społeczeństwa demokratycznego ${ }^{13}$.

Podsumowując punkt Tło historyczne, można zaobserwować na przestrzeni czasów przedziwny proces scalania się tradycji religijnej i patriotyzmu Polaków. Jest to fenomen pośród wielu krajów Europy. To brak wolności narodowej, zmaganie się o wolność, o przetrwanie spowodowały, że Polacy w trudnych chwilach szukali i znajdowali jedyne oparcie w rodzinie i w Kościele. Tu się uczyli, tu pielęgnowali swój język, historię, kulturę. Od rozumienia tego procesu zależy sukces poznania tej rzeczywistości, której na imię jest: polskość.

\section{Błogoslawiona Bolesława Lament - osoba i dokonania}

Bł. Bolesława Lament urodziła się 3 lipca 1862 r. w Łowiczu w rodzinie katolickiej i patriotycznej. Podkreślenie jej wiary i patriotyzmu jest bardzo ważne ze względu na jej przyszłą działalność. Odniesienie do religii, do poczucia tożsamości narodowej było podstawowym kryterium jej rozwoju, pojęcia, kim ona jest. Błogosławiona nie miała wyboru, musiała wzrastać, uczyć się w szkole rosyjskiej. Ze względu na swe pochodzenie doznawała wielu upokorzeń. To doświadczenie nie złamało jej i nie przesłoniło obiektywnej prawdy o godności osobistej Rosjan i ich wiary prawosławnej. Z sukcesem w 1876 r. ukończyła trzyklasowe progimnazjum i uzyskała prawo do nauczania w szkole elementarnej. Edukacja bł. Bolesławy trwała dalej w zawodzie krawieckim. W $1882 \mathrm{r}$. Błogosławiona po zdaniu egzaminu mistrzowskiego otworzyła własny zakład krawiecki w Łowiczu. Jednak jej pragnienia szły dalej, chciała poświęcić swoje życie Bogu w zakonie. Dlatego w 1884 r. wstapiła do Zgromadzenia Sióstr Rodziny Maryi w Warszawie. W zgromadzeniu pozostała osiem lat. W tym czasie jako misjonarka świecka, było to związane z warunkami konspiracji, pracowała w kilku miastach w Rosji. Dzięki tej pracy pogłębiła swoją wiedzę na temat religii, kultury i panujących relacji pomiędzy różnymi ludami zamieszkującymi imperium rosyjskie. W 1892 r. opuściła zgromadzenie z zamiarem wstapienia do zakonu kontemplacyjnego - do Wizytek w Krakowie. Jednak, kierując się wolą swego spowiednika ks. Zygmunta Mścichowskiego, pozostała w domu rodzinnym i oddała się pracy wychowawczej pośród dzieci i młodzieży. Za radą tego samego kapłana w 1894 r. przeniosła się do Warszawy i tam miedzy innymi prowadziła dalej działalność oświatową wśród miejscowej biedoty. W Warszawie wstapiła do III Zakonu św. Franciszka dla osób świeckich jako tercjarka.

${ }^{13}$ Zob. E. Miller, dz. cyt., s. 62-71. 
Z biegiem czasu została ustanowiona przełożoną tej wspólnoty. W tym czasie jej kierownikiem duchowym został kapucyn o. Honorat Koźmiński. To za jego radą w 1903 r. Błogosławiona udała się do Mohylewa, aby na Kresach podjąć opiekę religijno-patriotyczną nad polskimi dziećmi. W ten sposób bł. Bolesława odpowiedziała na wezwanie Boże jak i na prośby miejscowej ziemianki Leontyny Sianożęckiej o pomoc, o ustrzeżenie dzieci przed rusyfikacją. Tu na miejscu bł. Bolesława zdała sobie sprawę z tego, że bez zorganizowania się, bez struktur nie można skutecznie działać. Dlatego w 1905 r. założyła przy pomocy jezuity o. Feliksa Wiercińskiego nowe zgromadzenie zakonne Towarzystwo Św. Rodziny (obecna nazwa funkcjonuje od 1929 r.). Oczywiście ten nowy instytut został założony w ścisłej konspiracji. Na zewnątrz Siostry pracowały jako świeckie panie. W 1907 r. ze względu na trudności finansowe Zgromadzenie przeniosło się do Petersburga. Po bardzo trudnym początku przyszedł czas na dynamiczny rozwój instytutu. W ciagu paru lat Błogosławiona otworzyła dwie szkoły średnie. W 1913 r. Towarzystwo św. Rodziny liczyło 15 sióstr zakonnych i posiadało 3 placówki zakonne. Oprócz pracy w szkole Misjonarki angażowały się w pracę dobroczynna, liturgiczna, kulturalną przy parafiach, w praktyczną naukę zawodu dla dziewcząt, np. krawiectwo. Z pracą edukacyjną Siostry łączyły nauczanie i wychowanie religijne oraz patriotyczne, w tym naukę historii i języka polskiego. Czyniły to jednak w tajemnicy, ciesząc się zaufaniem zarówno uczniów, jak i miejscowej Polonii. Przez moment nastapił okres pewnej stabilizacji w pracy i życiu Sióstr. Jednak wraz z przejęciem władzy przez bolszewików, ich sytuacja uległa drastycznemu pogorszeniu. W 1918 r. władze rewolucyjne upaństwowiły szkoły razem $\mathrm{z}$ wyposażeniem. Bł. Bolesława wobec tych wydarzeń podjęła próbę osiedlenia części Sióstr w innych miejscowościach na terenie Rosji, ale ostatecznie w 1921 r. Misjonarki wyjechały do odrodzonej Polski. Pierwszym domem, który Siostry nabyły na własność, była kamienica w Chełmnie na Pomorzu. Tu po raz pierwszy Siostry założyły strój zakonny. Jednak i na ziemi ojczystej Zgromadzenie doznało wielu cierpień. Pomimo posiadania domu na własność, biskup chełmiński nie zgodził się, aby w diecezji ulokować nowicjat i dom generalny. Od tego momentu zaczyna się tułaczka Sióstr po różnych miejscowościach w celu osiedlenia. Dopiero w 1925 r. bł. Bolesława Lament otrzymała na ten cel pobernardyński klasztor w Ratowie od bpa płockiego Juliana Nowowiejskiego. Wraz z ustabilizowaniem sytuacji domu macierzystego Siostry mogły bez przeszkód poświęcić się pracy wychowawczo-duszpasterskiej w siedmiu placówkach, które w tym czasie posiadały. W $1927 \mathrm{r}$. bł. Bolesława stała na czele instytutu, który liczył 51 profesek, 12 nowicjuszek i 50 postulantek. Rozwój Zgromadzenia był zauważalny, ponieważ w 1935 r., kiedy Błogosławiona zrzekła się urzędu przełożonej generalnej, zakon liczył 174 profeski, 26 nowicjuszek i 9 postulantek. Od 1927 r. do 1934 r. za jej rządów powstały 23 nowe placówki. Zakres obowiązków, jakie Siostry podejmowały, był bardzo szeroki. Członkinie Zgromadzenia pracowały w przytułkach, w sierocińcach, w przedszkolach, w szkołach, na wszelkiego rodzaju kursach, np. kroju i szycia. Była to też praca charytatywna, 
opiekuńcza w służbie zdrowia, w domach opieki, w noclegowniach, w internatach, na koloniach, praca przy parafiach. Siostry Misjonarki nie ograniczały się tylko do samej pracy zawodowej, ponieważ przekazywały swoim podopiecznym także treści prawd wiary, a tam, gdzie nie było kapłanów, spełniały posłannictwo animatorów liturgicznych. Były też animatorkami w przeróżnych wspólnotach religijnych czy bractwach, jak np. III Zakon św. Franciszka. Siostry, kierując się duchem apostolskim, już w 1933 r. dotarły do Estonii. To wszystko, co Siostry czyniły było podporządkowane charyzmatowi Zgromadzenia. Po wybuchu II wojny światowej Misjonarki podzieliły los całego narodu. Wiele z nich tułało się, ponieważ zostały wyrzucone przez okupantów ze swych domów, a niektóre $\mathrm{z}$ nich zostały uwięzione. $\mathrm{W}$ zasadzie praca Sióstr została przerwana, tylko w nielicznych ośrodkach ograniczono ją do minimum albo została wręcz zepchnięta do podziemia. W tym czasie takim centrum, wokół którego gromadziły się Siostry albo szukały pomocy, był Białystok. To tu od 1935 r. przebywała ich Założycielka. Bł. Bolesława interesowała się losem swych córek duchowych. Jednak sama, będąc sparaliżowana, nie mogła im wiele pomóc. Bł. Bolesława Lament umarła 29 stycznia 1946 r., a jej ciało zostało złożone w kościele w Ratowie. Po wojnie Zgromadzenie Sióstr Misjonarek, odpowiadając na głos Kościoła, włączyło się w nurt odnowy, jednoczenia i umacniania ludzi wierzących. W pierwszych latach po wojnie Zgromadzenie otworzyło szesnaście nowych placówek, z tego aż dziesięć na tzw. ziemiach odzyskanych. Siostry wznowiły swoją działalność w przedszkolach, w katechezie, na kursach krawieckich, przy prowadzeniu internatów dla młodzieży, w domach opieki dla dzieci, w tym dla dzieci umysłowo chorych, dla dorosłych, jako pielęgniarki, jako organistki, animatorki życia religijnego i liturgicznego przy parafiach. Ten entuzjazm, dynamizm pracy wychowawczo-duszpasterskiej szybko stłumili komuniści, najpierw w latach czterdziestych zwolnili Misjonarki z pracy w internatach, potem zostały usunięte ze żłobów i sierocińców. W 1954 r. Siostry musiały opuścić po raz pierwszy szkołę i przenieść się z nauczaniem religii do sal przykościelnych. Z przedszkoli i ze szkół Siostry ostatecznie zostały usunięte w $1961 \mathrm{r}$. Dłużej Siostry mogły pracować jako pielęgniarki i jako opiekunki w zakładach dla dzieci umysłowo chorych, co bardziej wynikało z braku odpowiednio przygotowanego personelu niż życzliwości władz. Ten stan rzeczy trwał do przełomu 1989 i 1990 r., wtedy władza partii komunistycznej załamała się w Polsce. Nastapiły procesy normowania się wzajemnych stosunków państwo-Kościół. W wyniku zaistniałych zmian Siostry podjęły na nowo swoją pracę, ale zawsze zgodnie z przesłaniem, jakie im zostawiła Matka Założycielka ${ }^{14}$.

Jeszcze trudniej przedstawiał się los czterech Misjonarek, które po 1945 r., po ustaleniu wschodniej granicy Polski, z własnej woli zostały w ZSRR. Przez

${ }^{14}$ Zob. tamże, s. 72-81; J. Babińska, Matka Bolestawa Maria Lament założycielka Zgromadzenia Sióstr Misjonarek Św. Rodziny (1862-1946), w: B. Bejze (red.), Chrześcijanie, Warszawa 1983, t. 10, s. 103-118; J. Bar, dz. cyt., s. 12-56. 
wiele lat żyły one w ścisłej konspiracji. Dopiero w 1969 r. został nawiązany osobisty kontakt pomiędzy nimi a całą wspólnotą w Polsce. Był to bardzo radosny, obiecujący znak na przyszłość. Ta radość została wzmocniona przez fakt zgłoszenia się do Zgromadzenia trzech miejscowych powołań: trzech sióstr Łuksza. Już w 1983 r. na Wschodzie do instytutu należało dziewięć profesek, cztery junioratki, trzy nowicjuszki, dwie postulantki ${ }^{15}$.

Po omówieniu życiorysu i dokonaniach bł. Bolesławy Lament warto ukazać osobowość Błogosławionej, po to, aby przedstawić ją jako wzór pedagoga, wzór człowieka, którego można naśladować. Wspomniano już wcześniej, że wiara i patriotyzm Błogosławionej są ważne, gdy omawia się jej działalność apostolską. Ta sama wiara i patriotyzm miały także decydujący wpływ na kształtowanie się jej osobowości i jej powołania zakonnego. Na podstawie analizy pozostawionych pism bł. Bolesławy grafolog Aleksandra Obrębska określiła jej cechy osobowości. Stwierdziła, że Błogosławiona była osobą nad wyraz inteligentną i wszechstronnie uzdolniona, miała duże poczucie piękna i harmonii. Posiadała dobrą pamięć i wyobraźnię. Odznaczała się szerokim zakresem zainteresowań. Była uczuciowa, dlatego swoje uczucia okazywała na zewnątrz, gotowa do poświęceń; jednocześnie była bardzo logiczna i rozsądna. Odznaczała się silną wola; była bardzo ambitna i zdyscyplinowana, pracowita i zaradna. Wymagała wiele od innych, ale i od siebie. Była zdolna realizować trudne cele, które sobie wyznaczyła. Odznaczała się dużym poczuciem godności osobistej ${ }^{16}$. Wymienione cechy osobowe Błogosławionej pozostawały w ścisłym zespoleniu z jej wiarą. To nadprzyrodzona wiara w Boga kształtowała ją, jej życie i jej powołanie. Jej wiara była głęboka i bezgraniczna, zwłaszcza tam, gdzie pojawiały się trudności. Ta wiara posiadała jeszcze jedna cechę, była to wiara żywa, stąd bł. Bolesława cieszyła się stałą świadomością obecności Bożej. Tak przeżywaną wiarą dzieliła się z tymi, których spotykała na drodze pracy apostolskiej, a przede wszystkim ze swoją wspólnotą zakonną. Błogosławiona zdawała sobie sprawę z tego, że wiara jest darem Bożym, dlatego dbała o ten dar. Prowadziła regularne życie modlitewne i sakramentalne. Czymś zwyczajnym dla niej był kult Eucharystii i Serca Bożego, a także codzienna adoracja. Wiara bł. Bolesławy przeszła próbę czasu, zwłaszcza podczas wojny i częściowego paraliżu ciała. Wtedy to dziękowała opatrzności Bożej, że może żyć w czasach, kiedy Kościół jest prześladowany. Złożyła heroiczny ślub, że nie odmówi Bogu żadnej ofiary, której On zażąda od niej, jako zadośćuczynienie za grzechy świata ${ }^{17}$. Błogosławiona łączyła cnotę wiary z nadprzyrodzoną miłością Boga i człowieka. O tym świadczy całe jej dzieło życia oraz dzieło założenia zgromadzenia misyjno-ekumenicznego. W swym poczynaniach bł. Bolesława kierowała się zawsze wolą Bożą i bezinte-

${ }^{15}$ Zob. L. Rojecka, Sprawozdanie na Kapitułę Generalnq z rozwoju i działalności Zgromadzenia na Wschodzie w okresie od 14.04.1969 do 05.1983 r. Załącznik nr 5a. S. B-1d (III-5a).

${ }^{16}$ Zob. J. Stabińska, dz. cyt., s. 85-86.

${ }^{17}$ Zob. E. Miller, dz. cyt., s. 84-85. 
resowną miłością. Dla niej, przykładem takiej bezinteresownej służby i miłości człowiekowi był Nazaret. Miłość Świętej Rodziny zawsze ją inspirowała. Pierwszym owocem tej miłości była jedność. Dlatego sprawa jedności stała się dla niej fundamentem, głównym przesłaniem, które Założycielka pozostawiła Siostrom swego Zgromadzenia. Jest to cel ich pracy; cel, który został potwierdzony przez Jezusa podczas modlitwy arcykapłańskiej w wieczerniku (zob. J 17,21). Szczególnym przejawem miłości, jaki Błogosławiona żywiła do braci z Kościoła prawosławnego, było pragnienie, aby wyodrębnić ze Zgromadzenia gałąz Sióstr obrządku wschodniego. Stanowiąc jedność ze Zgromadzeniem, Siostry te mogłyby skuteczniej działać na rzecz jedności podzielonych Kościołów ${ }^{18}$.

Matka Założycielka marzyła także, aby jej córki mogły docierać z misją głoszenia ewangelii do odległych zakątków świata. Za jej życia Siostry udały się do Estonii, kraju zasadniczo protestanckiego. Po jej śmierci, poczynając od 1963 r., Siostry zaczęły osiedlać się w Ameryce (USA), a w latach 1976-1985 jako pielęgniarki pracowały w Libii, w kraju muzułmańskim. W 1970 r. Misjonarki przybyły do Zambii, a potem w 1990 r. do Kenii ${ }^{19}$.

Bł. Bolesława Lament przez wszystkie lata życia zakonnego była związana ze szkoła, z kształceniem ludzi młodych. To z myślą o nich tworzyła coraz to nowe placówki wychowawczo-oświatowe. Klimat tam panujący, realizowane metody wychowawcze, sprzyjały integralnemu rozwojowi człowieka dojrzałego. Człowieka świadomego swej wiary i miłości ojczyzny. „Śledząc metody wychowawcze stosowane przez bł. Bolesławę Lament, można zauważyć, że dla niej podstawą pracy wychowawczo-duszpasterskiej była wiara w Boga. Bł. Bolesława stawiała przed młodym człowiekiem wymagania płynące z moralności chrześcijańskiej, które były wyzwaniem dla dzieci, by dążyć do ideału, jakim jest Chrystus. Bł. Bolesława rozumiała swoją posługę na rzecz dzieci w kategoriach służby, w jakimś sensie traktowała siebie jako pomoc, którą wychowankowie powinni „użyć, wykorzystać” w procesie samowychowania”"20.

Czyniąc końcowe podsumowanie tego punktu, można stwierdzić, że sam fakt beatyfikacji Matki Bolesławy, który odbył się w Białymstoku 5 VI 1991 r., jest publicznym potwierdzeniem, że Błogosławiona jest wzorem człowieka, którego warto naśladować w życiu codziennym oraz w pracy.

\section{Podstawy systemu wychowawczego}

Zgromadzenie Sióstr Misjonarek system wychowawczy wypracowało i realizowało dwutorowo, tzn. w odniesieniu do ludzi świeckich i do samych Sióstr,

${ }^{18}$ Zob. tamże, s. 86-87; J. Bar, dz. cyt., s. 56-62.

${ }^{19}$ Zob. S. Połoczańska, Siostry Misjonarki Św. Rodziny w Estonii 1933-45, Misyjna Rodzina XIV (1981) nr 3, s. 107-113; L. Puciłowska, Nasze siostry w USA, Misyjna Rodzina XIX (1986) nr 2, s. 70-77; Sprawozdanie na Kapitułę Generalną Zgromadzenia Sióstr Misjonarek Świętej Rodziny za okres 1 VII 1971-1 VII 1977, s. 18-19. S. B-1c (I-3).

${ }^{20}$ E. Miller, dz. cyt., s. 97. 
czyli na zewnątrz i wewnątrz instytutu. Poddamy analizie najpierw system wychowawczy, który był adresowany do ludzi świeckich, a konkretnie do wychowanek Zgromadzenia. Najbardziej dojrzałe ujęcie tego zagadnienia opracowała m. Łucja Czechowska $(† 1967)^{21}$. Matka Czechowska istotę wychowania zamknęła $\mathrm{w}$ formie trzech postulatów pedagogicznych, które zbudowała w formie pytań:

1. Jak pracować nad wyrobieniem serca?

2. Jak pracować nad wyrobieniem rozumu?

3. Jak pracować nad wyrobieniem woli?

Autorka termin serce odnosi się do rzeczywistości psychologicznej, czyli do zmysłów, uczuć, do pamięci, które mają wpływ na dziecko w całym procesie edukacyjnym. Jak pracować nad wyrobieniem serca? Należy dziecko tak prowadzić, aby ono samo odkryło własne możliwości, w tym własne ograniczenia. Dziecko, poznając stopniowo siebie i otaczająca go rzeczywistość, uczy się odróżniać prawdę i fałsz, dobro i zło. Zatem wychowanie polega na promocji i rozwoju dobra w dziecku, na ukazywaniu ideałów, które ono powinno nabyć, które pragnie zdobyć. Pragnienie dobra Matka łączy z moralnością dziecka, czyli z jego wiarą. Wiara z kolei ma zawsze motywować ucznia do wybierania dobra ze względu na Boga. W tym miejscu, jako metodę aktywizującą młodego człowieka do podążania za ideałem, Ł. Czechowska proponuje opowiadanie hagiograficzne, ponieważ konkretny przykład świętego przemawia, działa skutecznie na wyobraźnię podopiecznego. Dla Matki Łucji życie wiarą jest stałym i niepodważalnym czynnikiem procesu edukacyjnego. Dlatego postuluje, aby nie zaniedbywać praktyk religijnych. Nie chodzi tu o zmuszanie dziecka do tych praktyk, raczej przez własny przykład przełożeni mają zachęcić go do dobrowolnego uczestnictwa $\mathrm{w}$ życiu religijnym ${ }^{22}$.

Odpowiadając na pytanie, jak pracować nad wyrobieniem rozumu, intelektu dziecka, Łucja Czechowska stwierdziła, że zadanie to polega na uwolnieniu jego intelektu od natłoku powierzchownych uczuć, obrazów. Zabiegi te pozwola uczniowi dokonać logicznej, poprawnej oceny rzeczywistości w celu świadomego wyboru przekonań, postaw życiowych. Takie trzeźwe myślenie jest zwłaszcza potrzebne w przypadku prawd religijnych, ponieważ treści w nich zawarte często wymykają się poznaniu zmysłowemu. Z logicznym myśleniem Matka łączy dociekliwość umysłową ucznia, dlatego wychowawca ma budzić w nim pragnienie poznawania nowych treści, zdobywania ponadprogramowej wiedzy. Metoda, która wspomoże wysiłek uczenia się, ma być systematyczność i właściwa organizacja pracy ucznia. Z kolei ze strony nauczyciela uczeń ma prawo oczekiwać

${ }^{21}$ Zob. Ł. Czechowska, Notatki o wychowaniu. S. C-6 (VIII-3). [Brak daty, kiedy te notatki zostały napisane. Można jedynie przyjąć, że nastapiło to po 1929 r., ponieważ dnia 31 XII 1929 r. została opublikowana enc. Piusa XI Divini illius Magistri, której wpływ jest zauważalny w pracy m. Łucji]. Zob. E. Miller, dz. cyt., s. 195-200.

${ }^{22}$ Zob. Ł. Czechowska, dz. cyt., s. 10-17. 
rzetelnej wiedzy, bez niewygodnych przemilczeń. W momencie powstania różnic zdań, co może wynikać z odmienności myślenia, wychowawca z cierpliwością i szacunkiem dla osoby ucznia powinien wyjaśnić powstałe trudności ${ }^{23}$.

Najdłużej Łucja Czechowska zatrzymała się nad pytaniem: Jak pracować nad wyrobieniem woli? „Pisze ona, że wychować człowieka, to zbyt mało pouczyć lub przyzwyczaić go do dobra, ponieważ człowieka nie można traktować tylko jako przedmiotu wysiłków pedagogicznych, bowiem wychowanie nie dokonuje się poza jego wolnością. Wolność polega na tym, by stworzyć taki klimat współdziałania, w którym sam podmiot zaangażuje się w pracy nad samym sobą. Zauważa, że wolność, którą człowiek przeżywa w sposób świadomy i jednocześnie odpowiedzialny, jest sprzymierzeńcem wychowania"24. Uczeń ma zrozumieć, że wymagania, które stawia przed nim pedagog, zabezpieczają jego wolność. To samo odnosi się do nałożonych na niego kar. Matka Łucja w odniesieniu do problemu kar zaleca, aby ich unikać. Raczej wskazane jest cierpliwe upominanie i respektowanie porządku dnia. Autorka w tym miejscu zwraca uwagę na metodę wychowawcza, która polega na tym, aby w niektórych okolicznościach przełożony udał, że jest nieświadomy zaistniałego incydentu. Pozwoli to uczniowi dokonać samooceny, że dane zachowanie było niewłaściwe. Metoda ta daje podwójną korzyść: ze strony wychowanka jest to sposób na jego wzrastanie w prawdzie, a ze strony nauczyciela jest to sposób na okazanie pełnego zaufania podopiecznemu. Budującą metodą wychowawczą jest też sytuacja, kiedy przełożony po uświadomieniu sobie własnego błędu, jest gotowy do przeproszenia ucznia. Taka postawa wzmacnia autorytet wychowawcy w oczach dziecka. Matka zwraca uwagę, że sukces wychowania zależy od szczerego współdziałania nauczyciela i ucznia. To współdziałanie jednak musi być otwarte na współpracę z łaską Boża, ponieważ tylko Bóg w pełni potrafi zabezpieczyć wolność dziecka. Tylko dzięki łasce może dokonać się harmonijne scalenie władz duszy dziecka, tzn. jego zmysłów, rozumu i woli ${ }^{25}$.

Podstawy systemu wychowawczego, które opracowała m. Łucja Czechowska, są bardzo mocno osadzone w realiach odrodzonej Ojczyzny. Na wstępie i na zakończenie notatek o wychowaniu znajdują się dwa charakterystyczne teksty, które wyjaśniają kwestię celu powstania takiego systemu oraz zasad, które legły u podstaw stworzenia go przez Zgromadzenie. Siostry w budowaniu tego systemu i odpowiadających mu metod oparły się na przesłaniu uniwersalizmu, humanizmu wiary katolickiej. Niezaprzeczalnym walorem tego systemu jest to, że sprawdził się on w praktyce. Pierwszy tekst jest cytatem z Konstytucji z 1929 r.: „Jednym z głównych środków do osiagnięcia zamierzonego przez Zgromadzenie celu w pracy misyjnej: to wychowanie i nauczanie młodzieży (§ 184)". Drugi, końcowy tekst jest swobodnym zapisem: „Siostry będą uczennicom zwracały

${ }^{23}$ Zob. tamże, s. 17-21.

${ }^{24}$ E. Miller, dz. cyt., s. 197.

${ }^{25}$ Zob. Ł. Czechowska, dz. cyt., s. 2-4, 22-31. 
uwagę, że mają się wychowywać nie tylko na cnotliwe kobiety i na dobre katoliczki, ale i na pożyteczne obywatelki, bo to od obowiązków dobrej katoliczki jest nieodłączne" 26 .

System wychowawczy, który z kolei realizowano wewnątrz Zgromadzenia, wypływał z samej natury życia zakonnego i ustaw Zgromadzenia ${ }^{27}$. Przebiegał on na kilku etapach, w kolejności był to: postulat, nowicjat, juniorat, formacja stała po profesji wieczystej. Zawsze była to formacja intelektualna i duchowa. Natomiast w odniesieniu do środków, jakie były wykorzystane w tym systemie, były to: środki apostolstwa wewnętrznego oraz środki apostolstwa zewnętrznego. Te pierwsze wypływały z nakazu ustaw Zgromadzenia, które zobowiązywały Siostry, aby dążyły do świętości. Odbywa się ono przez zachowanie trzech ślubów prostych, są to: czystość, ubóstwo i posłuszeństwo. Świętość osobista Sióstr jest także niepodzielnie powiązana z nabywaniem cnót teologicznych, czyli wiary, nadziei i miłości. Szczegółowymi środkami apostolstwa wewnętrznego sa, np. modlitwa, post, cierpienie. Według bł. Bolesławy Lament Siostry powinny sobie cenić te środki i chętnie je podejmować dla wypełnienia charyzmatu instytutu. Podobnie przedstawia się sprawa ze środkami apostolstwa zewnętrznego, a są nimi: praca w szkole, w przedszkolu, w zakładach opieki społecznej itd., czyli jest to konkretna praca, którą Misjonarki spełniają na rzecz drugiego człowieka. Matka Bolesława uwrażliwiała współsiostry na sposób zaangażowania w spełnianiu swych obowiązków. Powtarzała, że motywy pracy Sióstr muszą być zawsze nadprzyrodzone ${ }^{28}$.

Przyjrzyjmy się teraz, chociaż pokrótce, poszczególnym etapom tej formacji oraz sposobami jej uzasadnienia. Trzeba jednak być świadomym faktu, że Zgromadzenie przez wiele lat funkcjonowało $\mathrm{w}$ niesprzyjających okolicznościach, były to np. lata totalitaryzmu komunistycznego, dlatego trudno było prowadzić tę formację, zwłaszcza od strony teoretycznej ${ }^{29}$.

26 Tamże, s. 33.

${ }^{27}$ Zob. Konstytucje (1929). Art. 2-3. S. A-2a-6; Konstytucje (1984). Art. 10-11; 87; B. Lament, Dyrektorium Zgromadzenia Sióstr Misjonarek Świętej Rodziny, Białystok 1944, t. I, s. 12, 23; t. III, s. 45-46, 169-174 [W cytowanym tekście zachowano pierwotną numerację stron]; Dyrektorium (1985). Art. 180.

${ }^{28}$ Zob. E. Miller, dz. cyt., s. 136-165.

${ }^{29} \mathrm{~W}$ latach czterdziestych, pięćdziesiątych i sześćdziesiątych Zgromadzenie ze względu na panującą w Polsce sytuację społeczno-polityczną nie mogło właściwie rozwijać działalności wychowawczo-duszpasterskiej wewnątrz własnej wspólnoty, dlatego kolejne przełożone generalne regulowały sprawę formacji i dyscypliny zakonnej przez swoje zarządzenia i okólniki. Do najważniejszych dokumentów należą: m. Maria Chrzanowska: Okólnik z 1947 r. S. B-2 (Ic-2; 3); Okólnik z 1949 r. S. B-2 (Ic-4); Okólnik z 1952 r. S. B-2 (Ic-9); Okólnik z 1953 r. S. B-2 (Ic-11); Okólnik z 1956 r. S. B-2 (Ic-16); m. Edmunda Kobylińska: Okólnik z 1959 r. S. B-2 (Id-1); Apel V Roku Wielkiej Nowenny z 1961 r. S. B-2 (Id-6). Poza wymienionymi dokumentami przełożone generalne włożyły wiele starań, by Siostry mogły korzystać z posługi kapłańskiej odpowiednich rekolekcjonistów, którymi z reguły byli ojcowie jezuici. W odniesieniu do spowiedników prosiły kurie biskupie o nominację na to stanowisko świątobliwych kapłanów, którzy wyróżniali się głębo- 
Postulat jest pierwszym etapem formacji zakonnej. $Z$ zasady trwał on jeden rok. W tym czasie kandydatka poznawała Zgromadzenie oraz charyzmat jego pracy. Postulantka przy pomocy instruktorki nowicjatu pogłębiała własną duchowość, nade wszystko jednak rozpoznawała prawdziwość swego powołania zakonnego. Formacja przebiegała w toku codziennej pracy danej placówki zakonnej, ponieważ początkowo nie było wspólnego postulatu. Postulantki miały jedynie kilka wspólnych zjazdów w roku. Dopiero od 1983 r. wprowadzono formację stałą dla wszystkich postulantek w Białymstoku. Od tego momentu można było poświęcić więcej czasu na uczenie postulantek katechizmu i prawd wiary. „Wychowanie w postulacie posiadało pozytywny wydźwięk. Zachęcano postulantki, aby rozwijały swoją miłość do Jezusa poprzez budowanie osobowych relacji do Niego, przez wyrabianie w sobie poczucia wdzięczności za dar powołania, a równocześnie, by uczyły się opanowywania własnych, naturalnych skłonności”30.

Nowicjat to kolejny, ważny etap formacji zakonnej. W czasach bł. Bolesławy nowicjat trwał jeden rok, a od 1953 r. przedłużono go do dwóch lat. Cel nowicjatu według Bł. Bolesławy jest potrójny: pozwala nowicjuszce poznać życie zakonne w tym konkretnym instytucie, przełożone mogą bliżej poznać kandydatkę, Siostra nowicjuszka z kolei wykorzystuje ten czas do własnej formacji i do umocnienia się w powołaniu ${ }^{31}$. Formacja w nowicjacie odnosiła się do ślubów zakonnych, czyli do ślubu czystości, ubóstwa, posłuszeństwa oraz do ustaw Zgromadzenia, mianowicie do Konstytucji i Dyrektorium. Podczas II wojny światowej Zgromadzenie nie przeprowadzało naboru nowych kandydatek. Po ustaniu działań wojennych wraz z przejęciem przez s. Stanisławę Derwiszyńską opieki nad nowicjatem rozpoczął się długi okres pozytywnego rozwoju dla tej instytucji. Mistrzyni odpowiadała za kształt formacji duchowej i intelektualnej we wspólnocie nowicjackiej. Sama opracowała większość wykładów w odniesieniu do zagadnień $\mathrm{z}$ ascetki. Wykładała prawdy katechizmowe i Konstytucje, podstawowe tematy z Pisma Świętego, poruszała także problemy z zakresu higieny i kultury dobrego zachowania. W późniejszym okresie również socjuszki przejmowały część wykładów na siebie, np. liturgikę, historię Kościoła. Po wprowadzeniu dwuletniego nowicjatu rozszerzono dla młodych Sióstr zakres wykładanego materiału z wymienionych dziedzin. Zmiany te dobrze wpłynęły na samą formację, która odtąd była bardziej pogłębiona, zintegrowana i zróżnicowana. Zróżnicowana

kim życiem wewnętrznym. Przełożone generalne zachęcały Siostry do stałego pogłębiania swojej wiedzy religijnej i zawodowej. W tym celu niektóre Siostry były kierowane do różnego typu szkół. W latach 1947-1967 kształciły się 123 Misjonarki, nie licząc tych, które uczestniczyły w wakacyjnych kursach katechetycznych. Dla całej wspólnoty zakonnej było organizowane dokształcanie religijne z zakresu dogmatyki, sakramentologii, chrystologii, eklezjologii, nauki społecznej Kościoła, etyki, Starego Testamentu, katechizmu, historii Kościoła, liturgiki i mariologii. (Zob. D. Karwowska, dz. cyt., s. 173-180).

${ }^{30}$ E. Miller, dz. cyt., s. $168-169$.

${ }^{31}$ Zob. B. Lament, dz. cyt., t. I, s. 3-4. Zapis ten znajduje swoje zasadnicze potwierdzenie w obecnych ustawach. (Zob. Konstytucje /1984/. Art. 108). 
tzn. trzystopniowa, ponieważ zaczęto zwracać większą uwagę na formację ludzką, chrześcijańską i duchową nowicjuszek. W 1955 r. nową mistrzynią została s. Sylwestra Połoczańska. Za jej czasów drugi rok formacji w nowicjacie traktowano jako ascetyczno-praktyczny. Nowicjuszki oprócz zwyczajnych prac gospodarczych podejmowały pracę np. w katechezie. Poza zajęciami praktycznymi pogłębiały swoje życie liturgiczne, stąd codziennie odbywały się kwadranse biblijne. $\mathrm{W}$ tej formie formacja $\mathrm{w}$ nowicjacie przetrwała przez wiele lat, a jej główne założenia są wciąż aktualne ${ }^{32}$.

Juniorat następuje po złożeniu przez Siostrę nowicjuszkę pierwszych ślubów zakonnych. Juniorat wynosił kolejno: trzy, cztery, a obecnie pięć lat. Sposób zorganizowania junioratu polegał na tym, że junioratki były grupowane w kilku większych domach Zgromadzenia. Tam na miejscu ich formacja biegła dalej pod opieką instruktorki junioratu. Dla każdej Siostry juniorat to czas stałego pogłębiania życia duchowego, zacieśniania związków ze wspólnotą i z Jezusem. To czas nabywania przez nią doświadczenia, w celu zdobycia takiej dojrzałości osobowej, iż będzie zdolna w sposób świadomy złożyć profesję wieczystą. Formacja w junioracie koncentruje się wokół liturgii, modlitwy, rad ewangelicznych i samowychowania. Dla pogłębienia formacji junioratek wewnątrzzakonna Komisja Pedagogiczna przygotowała poniższy program ${ }^{33}$, który był realizowany na ich wspólnych zjazdach: Rok I - modlitwa, pokuta i umartwienie, konieczność życia ewangelicznego; Rok II - dekrety o ekumenizmie i misjach; Rok III - nauka o Kościele na podstawie dokumentów soborowych (KK, KDK, DA, DZ); Rok IV - wybrane zagadnienia z teologii moralnej; Rok V - zagadnienia z teologii życia zakonnego ${ }^{34}$.

Przez wiele lat nie zwracano większej uwagi na sprawę formacji Sióstr po ślubach wieczystych. Taki wymóg zaistniał po Soborze Watykańskim II, po opublikowaniu dekretu Perfectae caritatis. Potem pojawiły się kolejne zapisy, które domagały się takiej formacji, były to Konstytucje Zgromadzenia z 1984 r. plus odpowiednia instrukcja z 1986 r. Według tego dokumentu: „Celem formacji ciagłej jest utrzymanie karności zakonnej oraz utrwalenie i pogłębienie tego, co siostra zdobyła w czasie formacji przed złożeniem profesji wieczystej" ${ }^{35}$. W codziennej praktyce chodziło o to, aby profeska scaliła swoje życie czynne i kon-

${ }^{32} \mathrm{~W}$ instrukcji z $1986 \mathrm{r}$. w odniesieniu do formacji nowicjackiej zostały przewidziane do omówienia następujące tematy: Okres wstępny: zagadnienia katechizmowo-ascetyczne, tematy informacyjne i z kultury życia. Wykłady w nowicjacie dla I roku: historia, Konstytucje i Dyrektorium Zgromadzenia, ascetyka, liturgika, kultura życia. Wykłady w nowicjacie dla II roku: Konstytucje i Dyrektorium Zgromadzenia, ascetyka, Pismo Święte: Nowy Testament, Dzieje Apostolskie i częściowo listy św. Pawła, dogmatyka, historia Kościoła. (Zob. Instrukcja o formacji zakonnej w Zgromadzeniu Sióstr Misjonarek Świętej Rodziny, Komorów 1986, s. 55-64. S. C-5a-IX). Zob. E. Miller, dz. cyt., s. 171-179.

${ }^{33}$ Zob. Dyrektorium (1985). Art. 220, 232.

${ }^{34}$ Zob. E. Miller, dz. cyt., s. 180-182.

${ }^{35}$ Zob. Instrukcja..., s. 89. 
templacyjne. Samowychowanie na tym etapie formacji powinno pomóc Siostrze: rozeznać, jakie potrzeby w niej górują; aby umiała ustalić hierarchię własnych potrzeb i odpowiadających im wartości; aby konsekwentnie i wytrwale dążyła do nabycia wartości wyższego rzędu, przy jednoczesnej rezygnacji z wartości niższego rzędu, np. potrzeb zmysłowych. Działanie według tego klucza jest możliwe tylko wtedy, gdy profeska w procesie samokształcenia oprze się na rzetelnej ascezie $^{36}$.

Na zakończenie tego punktu, w którym analizowano podstawy systemu wychowawczego wypracowanego przez Siostry Misjonarki, warto zwrócić uwagę na pewną zależność. Uzasadniając podstawy tego systemu, Siostry powoływały się na charyzmat Zgromadzenia. A przecież charyzmat to też duchowość tej konkretnej rodziny zakonnej. Zatem istnieje ścisła zależność pomiędzy charyzmatem i duchowością instytutu. Te dwie wartości wzajemnie wpływają na siebie. O charyzmacie była już mowa. Teraz zatrzymajmy się nad duchowością Zgromadzenia. Duchowość ta kształtowała się przez wiele lat, kształtowała się w konkretnych warunkach historycznych oraz konkretnej pracy Misjonarek. W centrum duchowości Sióstr znajduje się Chrystus. Tym istotnym momentem jest fakt wcielenia Jezusa. Właśnie ten Jezus posłuszny, ubogi, dziewiczy, kochający, podejmujący trud życia dla Boga Ojca jest wzorem dla bł. Bolesławy i jej córek duchowych. Misjonarki pragną naśladować Jezusa w swym życiu i powołaniu. Pragną tego samego dla ludzi, do których kierują swoją posługę. Chrystologia w rozumieniu Sióstr ma dwie konsekwencje. $Z$ jednej strony, jest to kult okazywany Jezusowi Chrystusowi, między innymi kult Serca Bożego i Eucharystii. Z drugiej strony, jest to praca apostolska na rzecz jedności ${ }^{37}$.

\section{Ośrodki pracy wychowawczo-duszpasterskiej}

Od samego początku były to bardzo zróżnicowane ośrodki pracy pedagogicznej. Jednakże jest jeden charakterystyczny podział tych placówek. Podział ten jest historyczny i odnosi się do daty $1918 \mathrm{r}$. Przed tą datą wszystkie placówki, w których były zatrudnione Siostry Misjonarki, działały w dużej mierze w konspiracji. Odnosi się to do tej części nauczania, która wiązała się z nauką języka polskiego. Przykładowo gimnazjum żeńskie, które założyła Błogosławiona w 1908 r. w Petersburgu w dzielnicy za Narwską Bramą. Placówka ta powstała w środowisku polonijnym, dlatego od samego początku była ona ośrodkiem myśli narodowej. Jednak ze względu na warunki polityczne, obok nauczania programowego w języku rosyjskim, prowadzono nauczanie tajne $\mathrm{w}$ języku polskim. Nauczanie to było poszerzone o historię, literaturę i kulturę polską. Gimnazjum

${ }^{36}$ Zob. M. Dawidziuk, Permanentna formacja, Misyjna Rodzina XI (1978) nr 3, s. 139-140; E. Miller, dz. cyt., s. 183-186.

${ }^{37}$ Zob. E. Miller, dz. cyt., s. 187-192. 
to stało na wysokim poziomie wykładanej wiedzy. Promowano w nim metodę pracy zespołowej oraz podstawy samorządności szkolnej. Pielęgnowano w niej nade wszystko katolickie życie religijne. Szkoła te przetrwała do 1918 r., po czym została zamknięta przez bolszewików. Natomiast inna sytuacja panowała w średniej szkole żeńskiej w Ostrołęce, gdzie Siostry pracowały w latach 1925-32, czyli były to lata niepodległości. Kolejny szczebel stanowiły szkoły zawodowe. Siostry pracowały w dwu ośrodkach: w Prużanie (1928-39) i w Białymstoku (1937-39). W szkołach tych nauczano młodzież żeńską przedmiotów praktycznych związanych głównie z krawiectwem i bieliźniarstwem. Podział ten zamykają szkoły parafialne. Zgromadzenie prowadziło te szkoły w Petersburgu, dlatego trzeba powrócić do daty sprzed 1918 r. Siostry uczyły dzieci najpierw przy parafii św. Kazimierza w latach 1907-1910, a potem przy parafii Nawiedzenia NMP, od 1912 r. do wybuchu rewolucji w 1918 r. Placówki te nie były tyle szkołami powszechnymi w sensie ścisłym, co raczej środowiskami opiekuńczo-wychowawczymi nad dziećmi polskimi, dlatego w nauczaniu skupiano się nad katecheza sakramentalna. Po powstaniu II Rzeczypospolitej Siostry katechizowały dzieci w strukturze aż 60 szkół powszechnych, głównie w archidiecezji wileńskiej oraz diecezji pińskiej38.

Najbardziej rozpowszechnionym sposobem kształcenia, w które angażowało się Zgromadzenie, były kursy dokształcające i zawodowe dla dziewcząt. I tak w Mohylewie początkowo taki kurs dokształcający prowadziła sama Założycielka od 1903 r., a potem po powstaniu zakonu w 1905 r. inne Siostry, aż do ustania tego kursu w 1907 r. Dziewczęta uczyły się tu kroju, szycia, haftu, trykotarstwa. Oczywiście Siostry nie zaniedbywały nauczania patriotycznego. Natomiast pełne kursy zawodowe mogły być prowadzone w warunkach suwerennej Ojczyzny. Pod opieką Zgromadzenia było 15 takich placówek, w następujących miejscowościach: Chełmno, Szreńsk, Wilno, Szereszew, Roś, Słonim, Rudka, Oszmiana, Łahiszyn, Krzywoszyn, Konstantynów, Holszany, Suchowola, Białystok, Świr. Nauka zawodu trwała przez dwa lata, dodatkowo uczono tu dziewczęta tkactwa i bieliźniarstwa. Podczas II wojny światowej działalność edukacyjna Sióstr prawie zamarła. Misjonarki pracowały z narażeniem życia jedynie w trzech szkołach powszechnych (Białystok, Suchowola, Świr) i na dwóch kursach zawodowych (Białystok, Błonie k. Warszawy). Najpowszechniejszą formą nauczania była katecheza sakramentalna przygotowująca dzieci do przyjęcia I Komunii św. Po wojnie sytuacja była nie mniej trudna. Siostry wznowiły pracę na kursach krawieckich w następujących miejscowościach: Olsztyn, Reszel, Lidzbark Welski, Chełmno, Konstantynów, Hajnówka, Białystok. Kętrzyn. Ze względu na straty pośród duchowieństwa polskiego najwięcej Sióstr zostało skierowanych do pracy w katechezie ${ }^{39}$.

${ }^{38}$ Zob. A. Gronkiewicz, Zgromadzenie Sióstr Misjonarek Świętej Rodziny w latach 1939-1947, Rzym 1979, s. 49.

${ }^{39}$ Dane opracowała s. Weronika Mackiewicz (zob. D. Karwowska, dz. cyt., s. 195-260; 
Ośrodki opiekuńczo-wychowawcze są kolejnymi miejscami, gdzie owocną posługę pełniły Siostry zakonne. Poniży przegląd rozpoczniemy od Zakładów Opieki Społecznej, chodzi tu o pracę Sióstr w szpitalach i w ambulatoriach. W okresie II Rzeczypospolitej prawie na każdej placówce na Kresach Wschodnich Siostry prowadziły ambulatoria. Wynikało to z konieczności ówczesnych warunków sanitarno-higienicznych, jak i biedy mieszkańców. Jedynie w dwu szpitalach powiatowych były zatrudnione Siostry jako pielęgniarki: w Pińsku i w Baranowiczach. Po wybuchu wojny w 1939 r. Siostry dalej kontynuowały posługę w szpitalach. W $1940 \mathrm{r}$. przyczyniły się do zorganizowania i prowadzenia szpitala w Legionowie. W 1944 r. jednostka ta została przeniesiona przez Rosjan do Jadowa w pobliże Białegostoku. W 1945 r. Siostry pielęgniarki wraz ze szpitalem powróciły do Legionowa. Po wojnie Siostry pracowały w kilku szpitalach, z których w większości zostały usunięte decyzją władz ${ }^{40}$.

Zakładami Opieki Społecznej o szczególnych i jednocześnie bardzo trudnych warunkach pracy były zakłady dla dzieci umysłowo chorych w Głodzinie i w Teodorówce. Placówka służby zdrowia w Głodzinie powstała w 1956 r. Siostry zostały zaproszone do pracy przez Zrzeszenie Katolików „Caritas”. W 1971 r. Zgromadzenie wycofało się z obsługi tego zakładu. Drugi zakład w Teodorówce był przeznaczony dla dziewcząt umysłowo chorych. W 1967 r. Rada Generalna Zgromadzenia postanowiła wycofać Siostry z tej miejscowości. Jednak wycofanie Sióstr było spowodowane naciskami władz państwowych, a nie wolną decyzją Zgromadzenia.

Misjonarki Świętej Rodziny ze względu na potrzeby społeczne pracowały jako pielęgniarki i opiekunki w Domach Opieki Społecznej, zwanych potocznie domami starców. Do najbardziej znanych placówek tego typu należał założony w 1938 r. ośrodek w Ratowie. Na tej placówce Siostry były zatrudnione do 1951 r., potem decyzją władz zostały zwolnione. Poza Ratowem Zgromadzenie opiekowało się trzema dalszymi Domami Opieki dla Dorosłych w Grójcu k. Warszawy, Białymstoku, przy ul. Dąbrowskiego i w Reszlu.

Kontynuując ten przegląd, przechodzimy teraz do internatów. Od samego początku, kiedy bł. Bolesława przybyła do Mohylewa, to założyła internat, który był powiązany z kursem dokształcającym. Internat został stworzony z myślą o biednych, zamiejscowych dziewczętach. W kolejnych latach Błogosławiona założyła internaty w Petersburgu (1908-1918) oraz w Wyborgu w Finlandii (1913-1914). Internaty prowadzone przez Misjonarki zawsze spełniały tę podwójną rolę: były przeznaczone głównie dla dziewcząt ze wsi oraz były miejscem ich edukacji religijno-patriotycznej. W odrodzonej Polsce Siostry prowadziły kolejno internaty

A. Gronkiewicz, Zgromadzenie..., s. 100-104). Zob. F. Kozłowska, Dane statystyczne Zgromadzenia na dzień 1 stycznia 1981 roku. Misyjna Rodzina XIV (1981) nr 1, s. 16; E. Miller, dz. cyt., s. 201-212.

${ }^{40}$ Zob. A. Gronkiewicz, Zgromadzenie..., s. 110-111; D. Karwowska, dz. cyt., s. 208-209, 212-214, 240-246, 258-260, 308-311. 
w Chełmnie (1922-1930), Ostrołęce (1926-1932), Wilnie (1927-1939), Prużanie (1928-1939), Brześciu (1928-1939) i Białymstoku (1938-1939). Po 1944 r. Zgromadzenie na nowo podjęło się organizacji i opieki nad internatami. Tego typu placówki były otwarte w Suchowoli, Białymstoku, Mrągowie i Kętrzynie. Misjonarki nie miały większych perspektyw na prowadzenie tych internatów, ponieważ najczęstszym powodem ich zamknięcia był nakaz władz komunistycznych.

Kolejnymi, ważnymi ośrodkami pracy opiekuńczo-wychowawczej, w których posługiwały Misjonarki, były żłobki. Przed wybuchem wojny w 1939 r. Siostry pracowały w trzech miejscowościach: w Słonimie (1927-1932), Brześciu (1931-1939) i Baranowiczach (1936-1939). Do żłobków były przyjmowane dzieci do trzeciego roku życia. Dzieci te rekrutowały się spośród sierot, nie brak było też dzieci porzuconych przez rodziców. Po 1945 r. Zgromadzenie Sióstr Misjonarek Świętej Rodziny prowadziło przez kilka lat trzy żłobki: w Mragowie (1945-1947), w Ornecie (1946-1949) i w Świdnicy (1948-1950). Także i w tym przypadku powodem zwolnienia Sióstr opiekunek był nakaz władz komunistycznych.

Dla dzieci starszych były przeznaczone sierocińce. Do tych placówek Siostry przyjmowały dzieci w przedziale od 5 do 16 lat. W wychowanie tych sierot Siostry wkładały wiele energii i serca. Siostry nie tylko zaspokajały ich potrzeby życiowe, ale przede wszystkim zastępowały im rodziców, kształciły je w różnych zawodach, przygotowywały je do dorosłego życia. W latach 1907-1939 Siostry pracowały w Petersburgu, Żytomierzu, Równem, Żydyczynie, Ławrowie, Szpanowie, Brześciu, Pułtusku, Prużanie, Baranowiczach ${ }^{41}$.

Podczas wojny Siostry otoczyły opieką sieroty z miejscowości Majówka (1941), ponieważ personel świecki porzucił te dzieci. Siostry przeniosły podopiecznych do Białegostoku na ul. Sitarską i troszczyły się o nie aż do roku 1947, kiedy sierociniec odebrano Zgromadzeniu. Po zakończeniu wojny Misjonarki przystapiły na nowo do organizowania domów opieki nad dziećmi. Oprócz Białegostoku wymienia się tu: Olsztyn (1946-1950), Mrągowo (1945-1947), Nowy Dwór (1945-1947) i Ornetę (1946-1949). Po kilku latach owocnej pracy w sierocińcach wszystkie Siostry zakonne zostały zwolnione. Powodem zamknięcia tych placówek była najczęściej decyzja władz państwowych.

Na końcu placówek opiekuńczo-wychowawczych, którymi kierowały Siostry Misjonarki, wymienia się przedszkola. Siostry opiekowały się głównie dziećmi $\mathrm{z}$ rodzin robotniczych, w przedziale wiekowy od 4 do 7 lat. W sumie prowadziły 21 przedszkoli. W poszczególnych placówkach przebywało od 20 do 150 dzieci $^{42}$.

Podczas działań wojennych (1939-1945) Misjonarki nie przerwały pracy w przedszkolach w Białymstoku przy ul. Dąbrowskiego i ul. Sienkiewicza (potem przy ul. Bema), w Wawrzyszewie, Legionowie i Błoniu. Stałą ich troską było zapewnienie dzieciom przynajmniej minimum pożywienia, a także zapoznanie wychowanków z podstawowymi prawdami wiary. Po zakończeniu wojny Siostry

${ }^{41}$ Zob. L. Puciłowska, dz. cyt., s. 78.

${ }^{42}$ Zob. tamże, s. 69-70. 
kontynuowały lub podjęły na nowo pracę w przedszkolach, w sumie w 19 placówkach $^{43}$. Rok 1961 jest taką graniczną datą, kiedy wszystkie Siostry zakonne zostały zwolnione z przedszkoli i szkó ${ }^{44}$.

Punkt o ośrodkach pracy wychowawczo-duszpasterskiej zamyka katecheza i animacja liturgiczna, która odbywała się w parafiach oraz w stowarzyszeniach i ruchach świeckich katolików. Tam, gdzie nie zawsze mógł dotrzeć kapłan, tam udawały się z posługą duszpasterską Misjonarki. Organizowały nabożeństwa $\mathrm{w}$ domach prywatnych, głównie w miesiącu maju, czerwcu, październiku i w okresie Wielkiego Postu. Liturgia domowa składała się ze śpiewów litanii, wspólnej modlitwy, czytania i komentowania Słowa Bożego oraz z wykładu prawd katechizmowych. Zdarzało się również, że na te nabożeństwa przychodzili prawosławni ${ }^{45}$. Siostry czasami z własnej inicjatywy zakładały niżej wymienione stowarzyszenia, zwłaszcza te, które odnosiły się do kultu Eucharystii. Takie postępowanie wynikało z charyzmatu i duchowości Zgromadzenia. Najczęściej jednak Misjonarki podejmowały posługę w już istniejących stowarzyszeniach i ruchach na terenie parafii. Zajmowały się Strażą Honorową, Apostolstwem Modlitwy, Krucjatą Eucharystyczna, Sodalicją Mariańską, Dziełem Rozkrzewiania Wiary, grupami Żywego Różańca, Tercjarstwem, Stowarzyszeniami młodzieżowymi ${ }^{46}$. Po II wojnie światowej Misjonarki mogły jedynie w bardzo ograniczonym zakresie rozwijać działalność w stowarzyszeniach katolików świeckich. Prowadziły głównie koła Żywego Różańca ${ }^{47}$.

Punkt Ośrodki pracy wychowawczo-duszpasterskiej zamyka obecny artykuł. Na zakończenie tego podrozdziału i tej pracy wypada stwierdzić, że Siostry Misjonarki wraz z ich założycielką bł. Bolesławą Lament odniosły sukces na gruncie pracy wychowawczo-duszpasterskiej. W ten sposób Zgromadzenie Sióstr Misjonarek Świętej Rodziny wpisuje się na trwałe do polskiej pedagogiki i katechetyki.

\section{L'attività educativa ed apostolica della Beata Boleslawa Lament e della Congregazione fondata da Lei - Missionarie della Sacra Famiglia (ne- gli anni 1905-1991) (Riassunto)}

L'articolo tratta del lavoro catechetico e pedagogico svolto da Beata Boleslawa Lament che insieme con le sue consorelle si dedicava ad estinguere Regno di Dio nella

${ }^{43}$ Zob. A. Gronkiewicz, Zgromadzenie..., s. 107-110; D. Karwowska, dz. cyt., s. 198-278.

${ }^{44}$ Zob. E. Miller, dz. cyt., s. 213-221, 231-135.

${ }^{45}$ Zob. L. Puciłowska, dz. cyt., s. 207.

${ }^{46}$ Zob. tamże, s. 117.

${ }^{47}$ Zob. D. Karwowska, dz. cyt., s. 201, 213, 234, 256, 269, 279, 341; E. Miller, dz. cyt., s. $222-226$. 
Bielorussia e nella Polonia nel corso degli anni del XX secolo. Il contributo delle Suore Missionarie della Sacra Famiglia è grande e la loro attività è presente fin d'oggi. L'articolo descrive peró solo attività svolta negli anni 1905 - 1991. Nell'anno 1905 è stata fondata la Congregazione, l'anno 1991 invece è la data della solenne beatificazione della fondatrice. Entrambe le date danno le rami in cui presentiamo ciò che le suore hanno fatto nel campo educativo ed apostolico della Chiesa.

Boleslawa Lament, nella sua vita, ha sperimentato le varie persecuzioni nel confessare la sua fede. E' nata il 3.07.1862 a Łowicz, in una città della Polonia, che in quell tempo era sotto l'occupazione da parte della Russia. Nell'anno 1903 è andata a Mohylew (oggi - Bielorussia) per educare i bambini ed i giovani, ed insegnarli la fede in Dio. Due anni dopo ha fondato la Congregazione delle Suore Missionarie della Sacra Famiglia, di cui carisma è l'unita della Chiesa, secondo il desiderio di Gesù pronunciato nel Cenacolo: "Perché tutti siano una cosa sola". Le suore lavoravano prima di tutto nel campo religioso ed educativo della Chiesa. La loro attività religiosa veniva svolta di nascosto, perché erano i tempi della persecuzione della Chiesa cattolica in Russia. Le suore intanto organizzavano l'orfanotrofi, le case per i bambini, insegnavano nelle scuole, facevano la catechesi nella Chiesa, insegnavano la gente a pregare, aiutavano a prepararsi ai sacrametni. Inoltre svolgevano il lavoro tra i poveri e sofferenti. Dopo la rivoluzione dell'ottobre 1917 in Russia, le suore erano costrette di tornare nella Polonia (1921), ma non hanno cessato il loro lavoro religioso ed educativo. La Congregazione crescreva in numero, ció permetteva di sviluppare la sua varia attività nel campo apostolico della Chiesa.

Oggi le Suore Missionarie della Sacra Famiglia lavorano in Polonia, Bielorussia. Lituania, Russia, Italia, negli Stati Uniti, ed in missione nell'Africa - Zambia, Kenia ed Tanzania. In questi vari posti del mondo loro portano il Vangelo a tutti quelli che non conoscono Dio ed a quelli che cercano di approfondire la fede cristiana e a tutti che sono in varie neccessità della vita. 